\title{
Minimally invasive techniques for the treatment of benign prostatic hyperplasia
}

\author{
Técnicas minimamente invasivas para o tratamento da hiperplasia prostática benigna
}

\author{
João Arthur Brunhara Alves Barbosa, Alberto Azoubel Antunes
}

Barbosa JABA, Antunes AA. Minimally invasive techniques for the treatment of benign prostatic hyperplasia / Técnicas minimamente invasivas para o tratamento da hiperplasia prostática benigna. Rev Med (São Paulo). 2018 May-June;97(3):314-9.

ABSTRACT: Benign Prostatic Hyperplasia (BPH) occurs in up to $80 \%$ of men older than 70 years. The prevalence of BPH increases with age, from approximately $25 \%$ of men at 50 years of age to 50 to $90 \%$ of individuals in their 8 th decade of life. Treatment options for lower urinary tract symptoms (LUTS) secondary to BPH have been long restricted to drug therapy and, after failure of the former, surgical treatment. However, prostate surgery is associated with risks such as bleeding, necessity of transfusion and ejaculatory dysfunction. Several novel and minimally invasive methods for treatment of BPH have arisen in the past years. Common to all of these techniques are a more favorable safety profile and varying rates of success and clinical improvement, however frequently inferior to standard surgical techniques. Patients who will benefit the most from these procedures are those who would not wish to undergo surgery, those at prohibitively high risk for surgery, and those wishing to avoid ejaculatory dysfunction secondary to trans-urethral resection of the prostate (TURP) or open resection. Mechanical devices such as Temporary implantable nitinol device and Urolift appear to provide satisfying results with a favorable safety profile. Persistence of improvement is still questionable since follow-up longer than 5 years is not available for these methods. Of note, these methods may be of limited performance for larger prostates, in special, Urolift for those with a large median lobe or a prostate larger than 100 grams. Similarly, novel techniques for tissue ablation, including convective water vapor energy, appear to offer promising and safe results, yet with limited follow-up. Prostate artery embolization (PAE) is another safe procedure and an option for patients who are not suited for surgery, with satisfying short and medium-term follow-up but unknown results at long-term.

Keywords: Prostatic hyperplasia; Prostate; Minimally invasive surgical procedures.
RESUMO: A hiperplasia prostática benigna (HPB) ocorre em até $80 \%$ dos homens acima de 70 anos. A prevalência da HPB aumenta com a idade, desde aproximadamente $25 \%$ dos homens com menos de 50 anos até $90 \%$ na oitava década de vida. Opções de tratamento para os sintomas de trato urinário inferior (STUI) secundários à HPB, por muito tempo, foram restritos a terapia medicamentosa e, na falência desta, tratamento cirúrgico. No entanto, as cirurgias prostáticas são associadas a riscos com sangramento, necessidade de transfusão, além da quase onipresente disfunção ejaculatória pós-operatória. Diversas técnicas novas e minimamente invasivas para tratamento da HPB surgiram nos últimos anos. Comum a todos esses métodos são um perfil de segurança favorável, porém com taxas de sucesso e de melhora clínica variáveis, mas frequentemente inferiores às encontradas nas técnicas cirúrgicas clássicas. Os pacientes que mais se beneficiam dessas técnicas novas são aqueles que não desejam passar por cirurgia; que possuem alto risco cirúrgico, além dos que desejam evitar a ejaculação retrógrada quase sempre presente após cirurgia aberta ou ressecção endoscópica da próstata. Dispositivos mecânicos como o TIND (Temporary implantable nitinol device, ou dispositivo temporário implantável de nitinol) e Urolift parecem oferecer resultados satisfatórios com um perfil de segurança amplamente favorável. A persistência da melhora dos sintomas é ainda questionável, uma vez que esses métodos ainda não contam com um seguimento superior a 5 anos. Também deve ser ressaltado que esses métodos podem ter sua performance limitada em próstatas excepcionalmente grandes. Em especial, o Urolift não deve ser indicado em pacientes com um lobo mediano proeminente ou com próstatas de peso estimado superior a 100 gramas. De forma semelhante, novas técnicas para ablação tecidual, como a ablação com energia convectiva de vapor de água, parecem oferecer resultados promissores e seguros, porém também com seguimento limitado. A embolização de artérias prostáticas é um outro procedimento seguro e uma opção para pacientes que não estejam aptos, pelo alto risco, a passar por cirurgias convencionais, com resultados de curto e médio prazo satisfatórios, porém também desconhecidos ao longo prazo.

Descritores: Hiperplasia prostática; Próstata; Procedimentos cirúrgicos minimamente invasivos.

Divisao de Urologia, Hospital das Clinicas HCFMUSP, Faculdade de Medicina, Universidade de Sao Paulo, Sao Paulo, SP, BR. Chefe do Setor de Próstata. ORCID: Barbosa JABA - https://orcid.org/0000-0001-9646-8588

Correspondência: João Arthur B. A. Barbosa. Instituto Central, Hospital das Clínicas da Faculdade de Medicina da Universidade de São Paulo. Urologia $-7^{\circ}$ andar. Av. Dr Enéas de Carvalho Aguiar, 255. Cerqueira César. São Paulo, SP, BR. CEP: 05403-000. Email: jbrunhara@gmail.com 


\section{INTRODUCTION}

$\mathrm{B}$ enign Prostatic Hyperplasia (BPH), as a histological phenomenon, occurs in up to $80 \%$ of men older than 70 years $^{1}$. Prostatic growth may manifest as different lower urinary tract symptoms (LUTS), including storage and voiding symptoms. The prevalence of $\mathrm{BPH}$ increases with age, from approximately $25 \%$ of men at 50 years of age to 50 to $90 \%$ of individuals in their 8 th decade of life $\mathrm{e}^{2,3}$. LUTS resulting from BPH may cause significant impairment in quality of life in older men, provoking at least mild modifications in lifestyle in up to $80 \%$ of patients with $\mathrm{BPH}^{4}$.

Treatment options for LUTS secondary to BPH have been long restricted to drug therapy or surgical treatment. Use of alpha adrenoceptor antagonists can be successful in reducing LUTS in short to mid term ${ }^{5,6}$, while inhibitors of the enzyme $5 \alpha$-reductase may decrease long term risk of urinary retention ${ }^{7}$. When medical treatment fails, surgery is generally offered as the gold standard for treatment of BPH, including endoscopic resection with either laser or cautery energy, laparoscopic or open surgery. However, in recent years, several minimally invasive techniques for treatment of BPH have arisen, presenting promising functional with lesser risks for complications and a shorter hospital stay ${ }^{8}$. To date, there is evidence for short-term results for most of such techniques, although long-term results are still expected. In general, results appear to be slightly inferior in terms of urinary obstruction, with favorable outcomes in terms of morbidity and complications. Among these, Prostate Artery Embolization (PAE), mechanical devices and alternate sources for tissue resection are the main groups of techniques proposed. Interestingly, these techniques also avoid postoperative ejaculatory dysfunction, a complication that up to $77 \%$ of patients would like to avoid if given the chance ${ }^{9}$.
In this review, we will outline the most relevant minimally invasive options for treatment of $\mathrm{BPH}$, the description of the techniques, the preliminary results, and limitations for each modality.

\section{Mechanical devices}

Several mechanical devices, being permanent or temporary, have been developed in recent years, aiming to keep the patency of the prostatic urethra without need for hospitalization or invasive procedures. These models have been perfected, with resolution of issues such as rejection to foreign body, post-procedure pain and device migration ${ }^{8}$. Below, we will detail principles of each existing technique and current evidence for each method, respectively.

\section{Temporary implantable nitinol device (TIND)}

This is a temporary device called Temporary implantable nitinol device (TIND, Medi-tate, Israel). It features a nitinol structure which is installed in the prostate through a transurethral approach with a 22 French cystoscope. The device is composed of an anchorage leaflet and radial structures which exert centrifugal force over the prostatic tissue to expand the prostatic urethra diameter (Figure 1). The installation of the device only requires light sedation and local anesthesia. This device is 50 millimeters long and covers the whole extension of the prostate. Device withdrawn is usually programed within 5 to 7 days from installation and is achieved with a bladder catheter, without need for hospitalization. The mechanism of action consists in induction of ischemia in the prostatic tissue, in the areas which are under pressure by the nitinol structure, hence remodeling the prostate and allowing for a larger urine flow through the urethra.

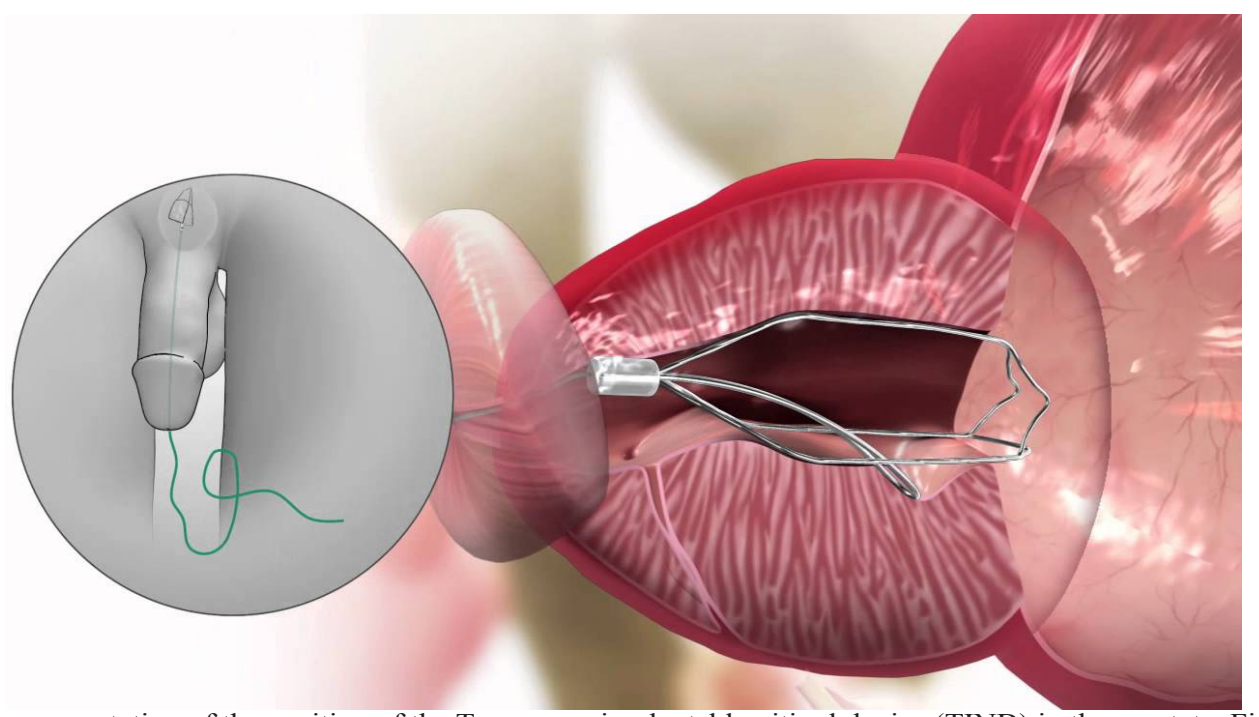

Figure 1. Model representation of the position of the Temporary implantable nitinol device (TIND) in the prostate. Figure obtained from website of the manufacturer: http://www.medi-tate.com/patients/itind/ 
A prospective study has evaluated the use of TIND in 32 patients with 1 year follow-up, assessing functional results, complications, feasibility and safety of use of this device ${ }^{10}$. Mean duration of the procedure was 5.8 minutes, with same day discharge being adopted after initial experience with the first 20 cases. Short-term complications occurred in $12.5 \%$ of patients (urinary tract infection, prostatic abscess, acute urinary retention, transient urinary incontinence). However, there were no cases of late or persistent complications after 1 years; also of note, reinterventions were not needed in any case to the end of follow-up. After 12 months, the authors noted a $67 \%$ raise of urinary flow rate and a $45 \%$ improvement in LUTS as evaluated with the International Prostate Symptom Score (IPSS). These authors concluded that the use of TIND is safe, easy, feasible and provides clinical efficacy in selected cases. There are currently 2 ongoing prospective studies further evaluating safety and performance of this device. TIND is not currently approved by the United States Food and Drug Administration, but it is approved for use in Brazil.

\section{Urolift}

Urolift is a permanent device (Urolift, Neotract, United States of America) that creates a continuous path through the prostatic urethra, from the bladder neck to the verumontanum, by means of implants applied bilaterally to the prostatic lobes through the urethra, pushing the lobes laterally and thus permitting increased flow through the urethra (Figure 2) ${ }^{11}$. Each implant is composed of an urethral end made of stainless steel, a non-absorbable polyethylene monofilament and a capsular end made of nitinol. These implants are installed using a cystoscope; usually 2 or 3 pieces are required for each prostatic lobe. These implants compress and push the prostatic lobes laterally, so as to free the prostatic urethra. The application of implants requires only local anesthesia, without necessity for hospitalization. Furthermore, the present of the implants does not preclude later surgical interventions eventually needed for benign or malignant disease. However, the efficacy of the procedure is limited if the prostate weight exceeds 100 grams; also of note, results are deficient if there is a large median prostatic lobe. Urolift has been approved by the United States Food and Drug Administration; to date, it is not approved for use in Brazil.

Urolift is the most studied minimally invasive mechanical device to date for the treatment of BPH. In a multicentric prospective randomized and controlled study including 206 patients, symptom improvement reached 50\% as per IPSS evaluation; urinary flow rate increased by $64 \%$ 3 months after the procedure ${ }^{12}$. Regarding the safety profile of the procedure, there were no complications or persistent side effects after 2 weeks from intervention; similarly, there was no impairment in sexual function as evaluated with the International Index of Erectile Function (IIEF). Patients from the same cohort, when re-evaluated after a 5 year follow-up, had maintained the short-term benefits previously demonstrated ${ }^{13}$. Patients presented symptom improvement, as compared to baseline, of $44 \%$ as per IPSS evaluation; quality of life improvement of $42 \%$ and an increase in urinary flow rate of $41 \%$. Other multicentric, prospective and randomized studies confirmed the effect of Urolift for the treatment of LUTS related to BPH, however less efficiently than Transurethral Resection of the Prostate (TURP) ${ }^{14,15}$. Notwithstanding, Urolift presented superior results in regard to post procedure recovery and sexual function, notably for not causing retrograde ejaculation. Such evidence have been corroborated by a recent meta-analysis including the currently existing data in the literature ${ }^{16}$.

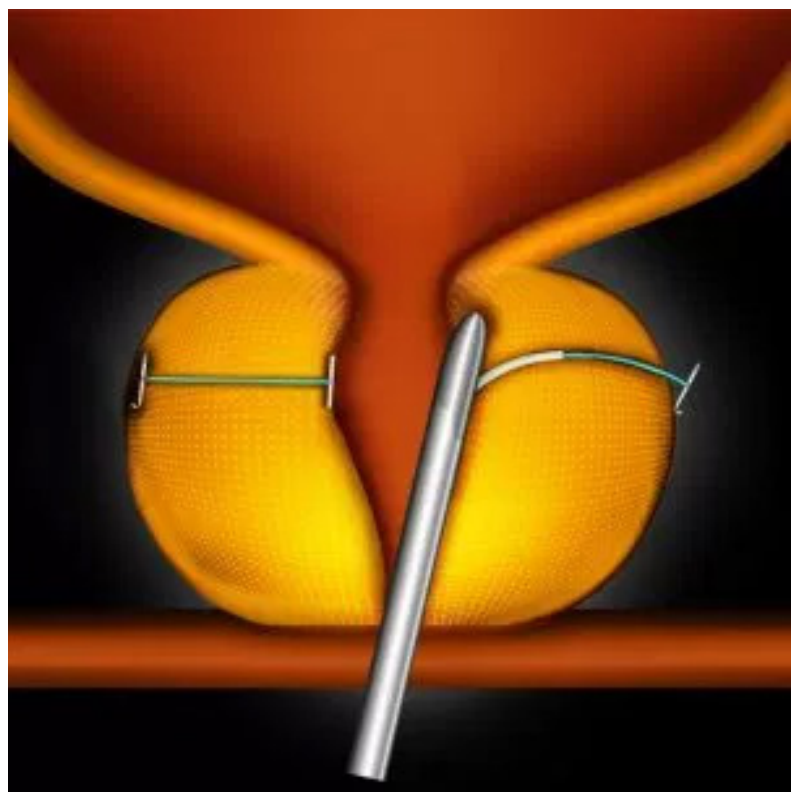

Figure 2. Model representation of the application of the Urolift device through a cystoscope. The implants pull the prostatic tissue laterally and liberates the prostatic urethra from obstruction. Figure obtained from the website of the manufacturer: https:// www.urolift.com/

\section{Tissue ablation}

The process of prostatic tissue ablation by means of minimally invasive procedures has been tried in the past, for instance with transurethral ablation with radiofrequency and microwave treatment ${ }^{17}$. However, long-term follow-up of such techniques did not reveal persistent benefit of these procedures, with a frequent necessity for surgery months after primary intervention.

In recent years, the development of thermal tissue ablation with water steam, through the use of convective radiofrequency, has allowed for new possibilities. A new system for the treatment of BPH with prostate ablation, called Rezum, consists in the use of radiofrequency to 
heat up water stored in the system turning it into steam; steam is then injected into the prostatic tissue and rapidly condensed, thus liberating thermal energy. This energy, in turn, leads to cell denaturation, tissue necrosis and vascular occlusion. This procedure is performed transurethrally with a cystoscope, requiring only local transrectal and urethral, with optional sedation. Steam applications are performed with a retractile needle through the cystoscope, with 1 centimeter of distance between injections (Figure 3). Patients are discharged on the same day of the procedure and should keep an indwelling bladder catheter for 1 week.

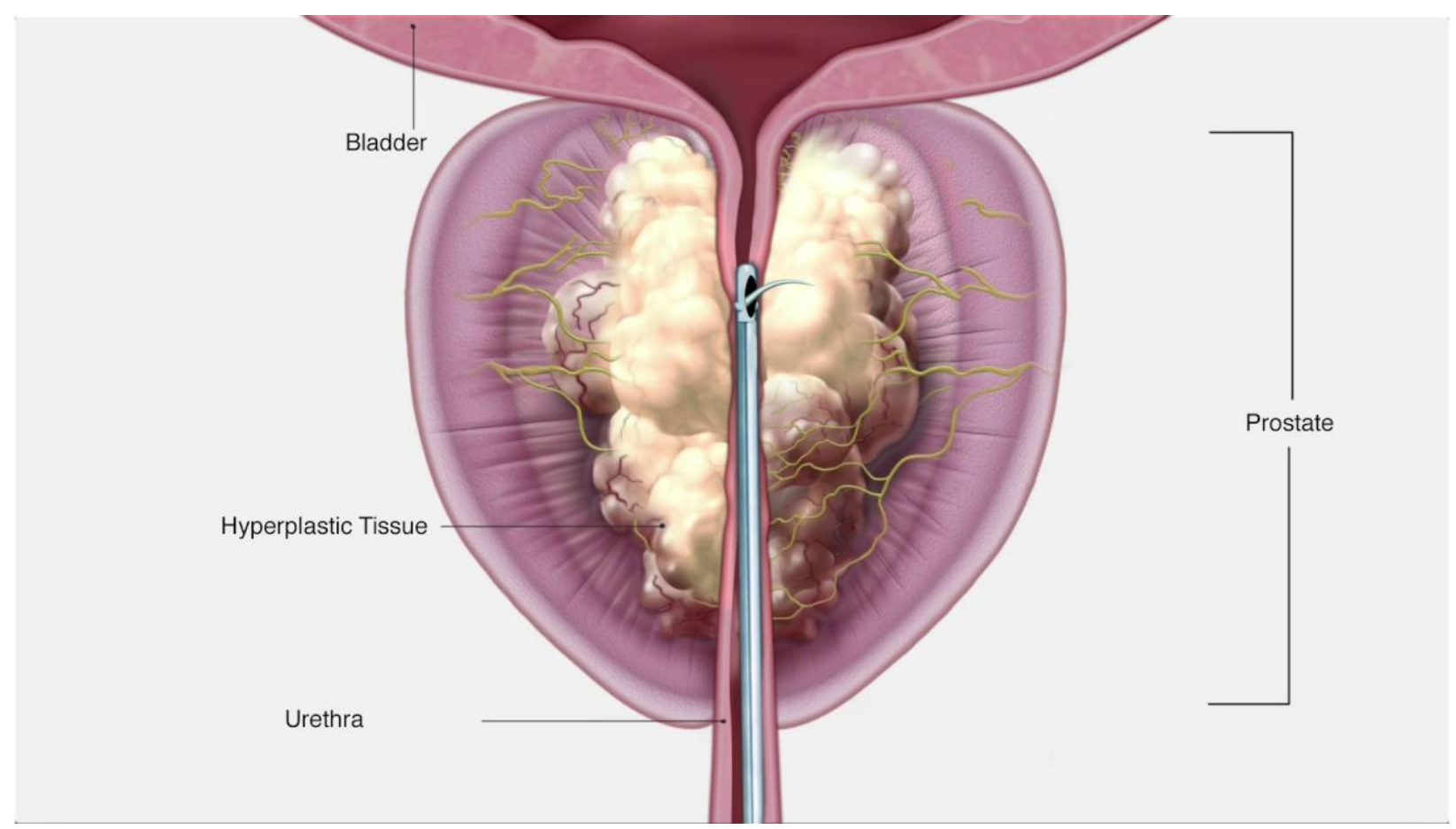

Figure 3. Model representation of the Rezum system with transurethral application of water steam with a retractile needle through cystoscopy. Figure obtained from the website of the manufacturer: http://www.rezum.com/the-rezum-system/

Available studies to date have demonstrated that, after procedure, there is an increase in urinary flow rate of up to 6 milliliters per second, as well as a 11-point improvement of symptoms as evaluated with the IPSS ${ }^{18,19}$. So far, efficacy of the results has been demonstrated at the end of a 2-year follow-up ${ }^{19}$. Furthermore, prostate volume in patients undergoing Rezum ablation has decrease by 17 to $28 \%{ }^{18,20}$. Significantly, sexual function is well preserved after this procedure, with ejactulatory dysfucntion occuring in only $3 \%$ of subjects; erectile function impairment was noted only among patients with a previous dysfunction ${ }^{18,21}$. Among main complications, urinary tract infection occurred in $17 \%$ of patients and a transient urinary retention after catheter withdrawn happened in $14 \%$ of cases, while other complications such as urethral stenosis occurred in less than $4 \%$ of patients ${ }^{18}$. Efficacy of the procedure was not related to prostate volume.

\section{Prostatic Artery Embolization (PAE)}

Prostatic Artery Embolization (PAE) was originally conceived as a treatment for refractory hematuria from prostatic etiology; however, it was later noticed that patients undergoing this therapy also improved in terms of LUTS. It subsequently started to be tested as a treatment for $\mathrm{BPH}$ among patients who were at high risk for a surgical procedure. PAE is performed by interventional radiologists through the femoral arteries with local anesthesia and allows for same day discharge. Major complications listed are transient ischemic proctitis, urethral burning, nausea and vomiting, with the short-term complications being identified as the "post-PAE syndrome"22. Also of note, is the risk of renal injury from contrast toxicity, as an angiography is needed in this procedure.

Data available to date indicate that PAE presents high technical success rates and provides benefits in the treatment of LUTS secondary to BPH. Overall, symptom improvement and urinary flow rate increases are inferior to those of standard surgical treatment; however, for certain patients who are not suited for surgery due to a prohibitive risk, PAE can be a valuable option. In a prospective trial at University of Sao Paulo including 30 patients randomized to TURP or PAE, both procedures were considered efficient and safe; however, symptom improvement was higher for TURP but the complication profile was safer for $\mathrm{PAE}^{23}$. A retrospective study including 630 patients undergoing PAE 
demonstrated clinical success at medium and long-term follow-up of $81 \%$ and $76 \%$, with major complications in only 2 patients $^{24}$. Yet, a recent meta-analysis of data available on PAE concluded that this technique should still be considered experimental, despite of safety evidence available ${ }^{25}$. Patients who are candidates for this procedure and not for surgery should be carefully selected and informed.

\section{CONCLUSIONS}

Several novel and minimally invasive methods for treatment of BPH have arisen in the past years. Common to all of these techniques are a more favorable safety profile and varying rates of success and clinical improvement, however frequently inferior to standard surgical techniques. Patients who will benefit the most from these procedures are those who would not wish to undergo surgery; those at prohibitively high risk for surgery and those wishing to avoid ejaculatory dysfunction secondary to TURP or open resection. Mechanical devices such as TIND and Urolift appear to provide satisfying results with a favorable safety profile. Persistence of improvement is still questionable since follow-up longer than 5 years is not available for these methods. Of note, these methods may be of limited performance for larger prostates, in special, Urolift for those with a large median lobe or a prostate larger than 100 grams. Similarly, novel techniques for tissue ablation, including convective water vapor energy, appear to offer promising and safe results, yet with limited follow-up. Prostate artery embolization is another safe procedure and an option for patients who are not suited for surgery, with satisfying short and medium-term follow-up but unknown results at long-term.

\section{REFERENCES}

1. Berry SJ, Coffey DS, Walsh PC, Ewing LL. The development of human benign prostatic hyperplasia with age. J Urol 1984;132:474-9. https://doi.org/10.1016/S00225347(17)49698-4.

2. Irwin DE, Milsom I, Hunskaar S, Reilly K, Kopp Z, Herschorn S, Coyne K, Kelleher C, Hampel C, Artibani W, Abrams P. Population-based survey of urinary incontinence, overactive bladder, and other lower urinary tract symptoms in five countries: results of the EPIC study. Eur Urol 2006;50:130615. doi: 10.1016/j.eururo.2006.09.019.

3. Chute CG, Panser LA, Girman CJ, Oesterling JE, Guess HA, Jacobsen SJ, Lieber MM. The prevalence of prostatism: a population-based survey of urinary symptoms. J Urol 1993;150:85-9. https://doi.org/10.1016/S00225347(17)35405-8.

4. Bertaccini A, Vassallo F, Martino F, Luzzi L, Rocca Rossetti S, Di Silverio F, Comunale L. Symptoms, bothersomeness and quality of life in patients with LUTS suggestive of BPH.
Eur Urol. 2001;40(Suppl 1):13-8. doi: 10.1159/000049872.

5. Lepor H, Williford WO, Barry MJ, Brawer MK, Dixon CM, Gormley G, Haakenson C, Machi M, Narayan P, Padley RJ. The efficacy of terazosin, finasteride, or both in benign prostatic hyperplasia. Veterans Affairs Cooperative Studies Benign Prostatic Hyperplasia Study Group. N Engl J Med. 1996;335:533-9. doi: 10.1056/NEJM199608223350801.

6. Kirby RS, Roehrborn C, Boyle P, Bartsch G, Jardin A, Cary MM, Sweeney M, Grossman EB; Prospective European Doxazosin and Combination Therapy Study Investigators. Efficacy and tolerability of doxazosin and finasteride, alone or in combination, in treatment of symptomatic benign prostatic hyperplasia: the Prospective European Doxazosin and Combination Therapy (PREDICT) trial. Urology. 2003;61:119-26. https://doi.org/10.1016/S00904295(02)02114-3.

7. Roehrborn CG, Siami P, Barkin J, Damião R, Major-Walker K, Nandy I, Morrill BB, Gagnier RP, Montorsi F; CombAT Study Group. The effects of combination therapy with dutasteride and tamsulosin on clinical outcomes in men with symptomatic benign prostatic hyperplasia: 4-year results from the CombAT study. Eur Urol. 2010;57:123-31. doi: 10.1016/j. eururo.2009.09.035.

8. Magistro G, Chapple CR, Elhilali M, Gilling P, McVary KT, Roehrborn CG, Stief CG, Woo HH, Gratzke C. Emerging minimally invasive treatment options for male lower urinary tract symptoms. Eur Urol. 2017;72:986-97. doi: 10.1016/j. eururo.2017.07.005.

9. Eberth B, Watson V, Ryan M, Hughes J, Barnett G. Does one size fit all? Investigating heterogeneity in men's preferences for benign prostatic hyperplasia treatment using mixed logit analysis. Med Decis Making. 2009;29:707-15. doi: 10.1177/0272989X09341754.

10. Porpiglia F, Fiori C, Bertolo R, Garrou D, Cattaneo G, Amparore D. Temporary implantable nitinol device (TIND): a novel, minimally invasive treatment for relief of lower urinary tract symptoms (LUTS) related to benign prostatic hyperplasia (BPH): feasibility, safety and functional results at 1 year of follow-up. BJU Int. 2015;116:278-87. doi: 10.1111/ bju. 12982 .

11. McNicholas TA, Woo HH, Chin PT, Bolton D, Fernández Arjona M, Sievert KD, Schoenthaler M, Wetterauer U, Vrijhof EJ, Gange S, Montorsi F. Minimally invasive prostatic urethral lift: surgical technique and multinational experience. Eur Urol. 2013;64:292-9. doi: 10.1016/j.eururo.2013.01.008.

12. Roehrborn CG, Gange SN, Shore ND, Giddens JL, Bolton DM, Cowan BE, et al. The prostatic urethral lift for the treatment of lower urinary tract symptoms associated with prostate enlargement due to benign prostatic hyperplasia: the L.I.F.T. Study. J Urol. 2013;190:2161-7. doi: 10.1016/j. juro.2013.05.116.

13. Roehrborn C, Gange S, Shore N, Giddens J, Bolton D, Cowan B, et al. Long term (5 year) results from the largest, prospective, randomized, controlled study of the minimally invasive prostatic urethral lift (PUL). Eur Urol Suppl. 2017;16:e334. Available from: https://www.eusupplements. 
europeanurology.com/article/S1569-9056(17)30258-0/pdf

14. Sonksen J, Barber NJ, Speakman MJ, Berges R, Wetterauer U, Greene D, Sievert KD, Chapple CR, Montorsi F, Patterson JM, Fahrenkrug L, Schoenthaler M, Gratzke C. Prospective, randomized, multinational study of prostatic urethral lift versus transurethral resection of the prostate: 12-month results from the BPH6 study. Eur Urol. 2015;68:643-52. doi: 10.1016/j.eururo.2015.04.024.

15. Cantwell AL, Bogache WK, Richardson SF, Tutrone RF, Barkin J, Fagelson JE, Chin PT, Woo HH. Multicentre prospective crossover study of the 'prostatic urethral lift' for the treatment of lower urinary tract symptoms secondary to benign prostatic hyperplasia. BJU Int. 2014;113:615-22. doi: 10.1111/bju. 12540

16. Perera M, Roberts MJ, Doi SA, Bolton D. Prostatic urethral lift improves urinary symptoms and flow while preserving sexual function for men with benign prostatic hyperplasia: a systematic review and meta-analysis. Eur Urol. 2015;67:70413. doi: $10.1016 /$ j.eururo.2014.10.031

17. Hill B, Belville W, Bruskewitz R, Issa M, Perez-Marrero R, Roehrborn C, Terris M, Naslund M. Transurethral needle ablation versus transurethral resection of the prostate for the treatment of symptomatic benign prostatic hyperplasia: 5-year results of a prospective, randomized, multicenter clinical trial. J Urol. 2004;171(6 Pt 1):2336-40. https://doi.org/10.1097/01. ju.0000127761.87421.a0.

18. Mollengarden D, Goldberg K, Wong D, Roehrborn C. Convective radiofrequency water vapor thermal therapy for benign prostatic hyperplasia: a single office experience. Prostate Cancer Prostatic Dis. 2017. doi: 10.1038/s41391017-0022-9.

19. Roehrborn CG, Gange SN, Gittelman MC, et al. Convective thermal therapy: durable 2-year results of randomized controlled and prospective crossover studies for treatment of lower urinary tract symptoms due to benign prostatic hyperplasia. J Urol. 2017;197:1507-16. doi: 10.1016/j. juro.2016.12.045.
20. Dixon CM, Rijo Cedano E, Mynderse LA, Larson TR. Transurethral convective water vapor as a treatment for lower urinary tract symptomatology due to benign prostatic hyperplasia using the rezum((r)) system: evaluation of acute ablative capabilities in the human prostate. Res Rep Urol. 2015;7:13-8. doi: 10.2147/RRU.S74040.

21. McVary K, Gange S, Gittelman M, Goldberg KA, Patel K, Shore ND, et al. Erectile and Ejaculatory Function Preserved With Convective Water Vapor Energy Treatment of Lower Urinary Tract Symptoms Secondary to Benign Prostatic Hyperplasia: Randomized Controlled Study. J Sex Med. 2016;13(6):924-33. doi: 10.1016/j.jsxm.2016.03.372.

22. Carnevale FC, da Motta-Leal-Filho JM, Antunes AA, Baroni RH, Marcelino AS, Cerri LM, Yoshinaga EM, Cerri GG, Srougi M. Quality of life and clinical symptom improvement support prostatic artery embolization for patients with acute urinary retention caused by benign prostatic hyperplasia. J Vasc Interv Radiol. 2013;24:535-42. doi: 10.1016/j. jvir.2012.12.019.

23. Carnevale FC, Iscaife A, Yoshinaga EM, Moreira AM, Antunes AA, Srougi M. Transurethral resection of the prostate (TURP) versus original and PErFecTED prostate artery embolization (PAE) due to benign prostatic hyperplasia (bph): preliminary results of a single center, prospective, urodynamic-controlled analysis. Cardiovase Intervent Radiol. 2016;39:44-52. doi: 10.1007/s00270-015-1202-4.

24. Pisco JM, Bilhim T, Pinheiro LC, Fernandes L, Pereira J, Costa NV, Duarte M, Oliveira AG. Medium- and longterm outcome of prostate artery embolization for patients with benign prostatic hyperplasia: results in 630 patients. J Vasc Interv Radiol. 2016;27:1115-22. doi: 10.1016/j. jvir.2016.04.001

25. Shim SR, Kanhai KJ, Ko YM, Kim JH. Efficacy and safety of prostatic arterial embolization: systematic review with meta-analysis and meta-regression. J Urol. 2017;197:465-79. doi: 10.1016/j.juro.2016.08.100.

Submitted for publication: May 29, 2018

Accepted in: June 30, 2018 